\title{
Article \\ Activity-Based Costing (ABC) and Its Implication for Open Innovation
}

\author{
Patricia Quesado ${ }^{1}\left(\mathbb{D}\right.$ and Rui Silva ${ }^{2, *(1)}$ \\ 1 School of Management, Polytechnic Institute of Cávado e Ave, 4750-810 Barcelos, Portugal; pquesado@ipca.pt \\ 2 Department of Economy, Sociology and Management, University of Trás-os-Montes e Alto Douro, \\ 5001-801 Vila Real, Portugal \\ * Correspondence: ruisilva@utad.pt
}

check for updates

Citation: Quesado, P.; Silva, R. Activity-Based Costing (ABC) and Its Implication for Open Innovation. J. Open Innov. Technol. Mark. Complex. 2021, 7, 41. https://doi.org/ 10.3390/joitmc7010041

Received: 15 December 2020

Accepted: 17 January 2021

Published: 21 January 2021

Publisher's Note: MDPI stays neutral with regard to jurisdictional claims in published maps and institutional affiliations.

Copyright: (c) 2021 by the authors. Licensee MDPI, Basel, Switzerland. This article is an open access article distributed under the terms and conditions of the Creative Commons Attribution (CC BY) license (https:// creativecommons.org/licenses/by/ $4.0 /)$.

\begin{abstract}
Activity-based costing system, commonly known as the ABC system, emerged as a costing method capable of overcoming the limitations of traditional costing systems in face of economic and technological developments, namely, the arbitrary and imprecise allocation of indirect costs from distortions in the imputation criteria. In the current context, the development of an adequate costing system is of extreme importance in organisations because they feel the need to properly manage the resources at their disposal and control their costs to achieve efficient and effective management. Thus, this study aims to analyse international publications on the activity-based costing system in recent years, identifying trends in evolution and future research opportunities. Based on bibliometric techniques, the outputs obtained in the Web of Science $(n=752)$ and Scopus $(n=1107)$ databases were analysed in bibliometrix $\mathrm{R}$ package to make a systematic mapping and review of the literature. After removing duplicates, we obtained a final output of 1419 articles. The analysis of these publications points to a growing trend in the publication of articles on ABC, highlighting publications in partnership and their dispersion in magazines from different areas. The bibliometric analysis carried out results on the authors' global research performance over time, and we highlighted the pioneering publications every five years and analysed the general evolution. When analysing based on publication authors over time, we highlighted the main research themes and countries where studies had been carried out. On the other hand, we also highlighted the collaborative network between institutions, authors, and countries over time.
\end{abstract}

Keywords: activity-based costing; bibliometric analysis; web of science; systematic literature review

\section{Introduction}

In recent years, traditional models of information and management control have been heavily criticised for failing to meet organisations' current needs, resulting from the globalisation of the economy, the internationalisation of markets, the increase in products and services offered, and technological development. In this sense, the increase in organisational competitiveness has led to an increase in demand for credible and timely information in organisations. Thus, in the current context, the development of an adequate costing system is of extreme importance in organisations. They feel the need to properly manage the resources at their disposal and control their costs to achieve management efficiently and effectively.

The activity-based costing (ABC) system emerged in the 1980s as a costing method capable of overcoming traditional costing systems' limitations in the face of economic and technological developments-namely, charging the arbitrary and imprecise cost of indirect costs resulting from distortions in the imputation criteria.

The ABC system considers activities that consume resources, which are causing costs, and not products, which only consume activities. As such, the products are a consequence of the activities strictly necessary to produce them and/or are a way of meeting customers' needs and expectations. 
Over the years, this costing system has been improved, and it was quickly realized that it allowed a strategic vision of the company by identifying its potentialities, its weaknesses, and opportunities for improvement, activities that add or do not add value, reflecting the organisational dynamics that determine costs with greater precision and comprehensiveness.

Given the importance and relevance of the theme, numerous studies have been carried out in organisations of different natures, sizes, and sectors of activity, which are materialized in master's theses, $\mathrm{PhD}$ theses, and publication of scientific articles.

The dissemination of bibliometric studies in the area of accounting has increased in recent years. These studies allow the researcher to identify journals and authors, investigated sub-themes, main research methods and approaches used, the economic sector and type of organisation, etc., highlighting possible research gaps, both in theoretical and in terms of practical terms that can be investigated in the future. As Zanievicz et al. [1] stated, the importance of these studies is related to the constitution of a consultation base on the state of the art of a given theme, which makes it possible to verify gaps in the generation of knowledge, researchers, and institutions dedicated to the theme and the evolution of theoretical basis that supports such investigations. On the other hand, Zimmerman [2] stated that the empirical literature in management accounting has failed to produce a substantial body of accumulated knowledge, unlike other accounting research areas, requiring scientific research that produces an accumulated body of knowledge.

In the management accounting literature, the $A B C$ system is a rapidly expanding area that has raised interest among researchers, but it needs bibliometric studies to direct research within this vast area of activity and considerable dispersion among authors in the field because it is a major concern if a few results were to be compared. Conducting bibliometric studies in the $\mathrm{ABC}$ area is a fundamental resource in the dissemination of scientific production, achieving its purpose through a technique capable of measuring the influence of researchers or journals and making it possible to trace their profile and trends, as well as highlighting thematic areas (ABS implementation process, $A B C$ benefits, $A B C$ critical aspects, etc.). The development of bibliometric studies, particularly in the area of management accounting, is extremely important in the sense of providing indicators capable of revealing its origin in academic production, the degree of evolution of knowledge, the scenario in which scientific investigations are inserted, as well as serving as a guide for future studies.

In this sense, the present research has the following research question as to its study problem: what types of scientific studies have developed about the $\mathrm{ABC}$ system in recent years?

Because of the above question, this work has as main objective to analyse, through a bibliometric study, the international publications in recent years on the $\mathrm{ABC}$ system and identify trends of evolution and opportunities for future research. The research's relevance is to draw a general profile about the scientific production on the $A B C$, provide historical and statistical data for the strengthening of the studies in this area of knowledge, and be useful to the researchers who intend to make future investigations in the area.

The work is structured as follows: initially, we present a brief theoretical framework on the $\mathrm{ABC}$ (addressing the concept, its main advantages, and critical aspects), with a review of bibliometric studies and a literature review. Subsequently, we present the methodology that guided the investigation and the main results obtained. Finally, we highlight the final considerations, limitations of the study, and suggestions for future research.

\section{Literature Review}

Traditional costing systems were based on indirect costs to products, focusing mainly on direct labour. These systems were developed when the main factors of production were raw materials and direct labour, where technology was considered stable, and the products offered to the market were limited [3,4]. 
With the appearance of new technologies and sophisticated production methods, there was an increase in competition and customer demand, reducing the weight of direct labour in the total production cost of organisations. In turn, indirect costs came to have a significant weight in most organisations' cost structures [5-8].

Bužanin [9] (p. 20) argued that 'the key changes in both environment and business of companies, which happened in the last few decades have brought to the development and possibility of use of $\mathrm{ABC}$. According to that, the basic assumptions of creating competitive success have changed. Modern business conditions, application of new technologies, higher demands of consumers and greater competition have made traditional cost accounting unreliable in giving information about costs and cost prices. Competitive success of companies, in modern business conditions, depends mostly on its ability to engage and use efficiently its material and non-material resources, ability to adapt quickly to the constant changes in the environment and ability to recognize and satisfy the changes needs and requirements of consumers, before anyone else'.

Against this backdrop, organisations sought a costing system capable of supporting the new product strategy and solving the problem of sharing indirect expenses. Faced with this issue, Johnson and Kaplan published "Relevance Lost-The Rise and Fall of Management Accounting" in 1987, from which the ABC system gained popularity, with the research spreading in the academic world and its application increasing in the business world $[10,11]$.

The ABC system emerged in the 1980s in the United States, intending to help organisations control their costs better and maintain themselves more efficiently in the market and increasing its popularity due to its applicability to different types of industries [12,13].

Cooper [14] and Kaplan [15] stated that ABC is a system designed to provide clearer information about the production, support activities, and product costs so that managers can focus their attention on products and processes with higher consumption of resources. $\mathrm{ABC}$ is a costing system in which the crucial objective is to provide management with more useful and accurate information, both on the cost and profitability of the business processes themselves [16]. Park et al. [17] added that ABC emerges as an innovation in management accounting to address traditional systems gaps.

According to Cooper and Slagmulder [18], the basic idea of ABC is that activities consume resources and generate costs, while products consume activities and absorb their costs, that is, it is not the products that consume resources. It is necessary to understand the behaviour of the costs of the activities involved in the process, finding the relationships between the products and the activities reflected in the cost driver. The cost driver is the basis of $A B C$ because it represents how costs are attributed to activities, seeking to trace the source of the cost and establishing a cause-effect relationship [19,20]. For Cokins and Hicks [21], a cost driver is used as a factor of the logical relationship between the resources and activities funded or between activities and cost objects, that is, it is a causal factor that influences the level and performance of activities and the consequent consumption of resources.

According to Kaplan and Anderson [22] and Compton [23], the standard procedure for implementing the $\mathrm{ABC}$ system begins with the identification and mapping of the relevant activities that are performed in the organisation, as well as with the identification of the resources that will be used in carrying out each activity that is part of the company's operation. Major and Vieira [24] (p. 315) argued that 'to implement an ABC/M system' successfully 'requires knowledge of a technical nature, but also, involves questions of a political and cultural behavioural nature'. It is essential to evaluate the company in economic and technical terms early because it is expected that the benefits are greater than its cost, making it essential to assess whether it will be possible to identify the activities.

There are several advantages mentioned in the literature regarding the application of $\mathrm{ABC}$ in organisations. Thus, according to Khodadadzadeh [25], ABC allows for identifying which products or services are not profitable for the company, thus eliminating them and adjusting the price of products or services whose prices are improperly practised. 
According to Cooper and Slagmulder [18], the system's main advantage is to reduce costs and simultaneously improve the company's strategic position. Besides, it highlights the actual cost calculation and improves the decision-making process by providing reliable information.

Kalicanin [26] pointed out that ABC's information is essential for company managers when evaluating alternative ways of managing the business and making comparisons with other companies. As such, it is clear that $\mathrm{ABC}$ can be invaluable in formulating and implementing business strategies.

Arora and Raju [27] and Kaplanog [28] added that, because the information is more detailed, facilitating decision making makes it possible to reduce costs and identify activities that do not add value to reduce or eliminate them. Thus, the ABC costing method can improve the organisation's performance in different ways, such as helping organisations become more efficient and effective, providing information on where resources are being spent and where the money is being earned or lost, and identifying the activities that add or do not add value to the product or service. For Haroun [29], the ABC system provides more accurate cost estimates since they are based on the activities performed, allowing managers to estimate the effects of different production processes and service methods, respectively, on the product or service costs.

The results of the study of Al-Dhubaibi [30] (p. 179) 'show that the degree of ABC implementation success positively influences the extent of its use, the magnitude of benefits that have been obtained, and the overall user satisfaction with the system. These findings imply that irrespective of the characteristics of the company or the features of the system, the way the companies implement $\mathrm{ABC}$ might determine how much benefits can be gained and to what extent the system could be used'.

Nevertheless, some authors also point out some critical aspects, among them, Pietrzak et al. [31], Stratton et al. [32], Askarany and Yazdifar [33], and Bornia [34], who state that many organisations do not adopt the ABC system due to the complexity, difficulty, and cost involved in its implementation and maintenance. Kaplan and Anderson [22] highlighted the difficulty and complexity related to identifying the various activity drivers. Fito et al. [35] considered that implementing the $A B C$ model has been interrupted due to conceptual problems. In turn, according to Ouassini [36], the adoption of the ABC system has a very high software cost, requiring investment in staff training. Gosselin [37] warns of the so-called 'ABC paradox', stressing that, while academics and consultants emphasise the model's superiority, the percentage of companies' adoption is low. For Rankin [38], the determination of the contextual factors predicting the adoption of the $\mathrm{ABC}$ system may facilitate the perception of the low adoption rates registered in different countries. According to Vedernikoca et al. [39], the traditional costing system has received criticism resulting from the arbitrary allocation of indirect manufacturing costs. As an important initiative to address its weaknesses, once costs and their determination play a critical role in all manufacturing companies, new costing methods such as the time-driven activity-based costing (TDABC) have emerged. Stonciuviene et al. [40] suggest the integration of ABC and lean accounting into full cost calculation.

Because of these critical aspects, companies should consider whether they need the $\mathrm{ABC}$ system, with some authors referring to some characteristics of organisations that can implement this method and justifying its implementation practically in those companies where indirect costs represent a significant percentage of the total costs; in industries with extensive and diversified production of products or services for serving different consumers; and those who work with diversified clients, who require specific or additional services [24,41-44]. Nevertheless, in the study of Aljabr [45], the results of the residual analysis showed that none of the examined key factors of competition, indirect costs, production complexity, and information technology quality (IT quality) affect $\mathrm{ABC}$ adoption as an optimal costing system design from the viewpoint of the matching form of fit.

We can also find some bibliometric studies in the literature that are carried out on this theme. Stefano et al. [19], for example, used the international databases 'ISI Web of 
Knowledge' and 'Scopus' to conduct a study during 1990-2011 and structure a bibliographic portfolio to address the application of the $A B C$ method in the services sector; they concluded that most applications of the $\mathrm{ABC}$ method are in organisations that provide health services, the $A B C$ method is used in its traditional or adapted form and sometimes integrated with another type of tools such as quality function deployment (QFD) or analytic hierarchy process (AHP), and most works use the ABC system to identify the activities that add value and those that cause losses in order to improve their productivity and competitiveness. According to the authors mentioned above, for the implementation of $A B C$ to be successful, it will be necessary to commit top management so that all objectives are in agreement with the strategy, quality, and performance evaluation. Besides, managers need to be aware of the time required for this implementation and experience in the use of information technology.

Zanievicz et al. [1], in a study they carried out on the costing methods most presented in the Brazilian Congress of Costs during 1994-2010, observed that the ABC system was the most researched method, followed by the theory of restrictions and target costing. In 2008, Diehl and Souza [46] carried out a study on publications about ABC in scientific events, intending to analyse the characteristics of scientific publications about $A B C$ in editions of the Brazilian Congress of Costs and verifying the growing number of articles produced annually on the researched subject.

Barsanti and Souza [47] analysed the scientific production carried out on the ABC system from 2002 to 2015 based on empirical research published in Brazilian accounting journals. Regarding the authors' profile, they found that most of them are male $(60.18 \%)$ and that $28.7 \%$ of the studied sample have a PhD. They observed the preference for the development of works in partnership. Concerning bibliographic references, they highlighted the more significant presence of books and journals, with a marked preference for international sources. They also verified the predominance of exploratory and qualitative research, especially the case study, and interviews as data collection methods. Conclusions were similar to those obtained in the study by Souza et al. [48], which aimed to analyse the research published on the ABC system between 2001 and 2010 in the leading Brazilian accounting journals.

Finally, Gosselin [49] surveyed studies carried out during 1990-2005 to determine the $\mathrm{ABC}$ adoption rate, noting that despite the numerous advantages associated with the model, the implementation rate was significantly reduced in most studies.

\section{Methods}

In this study, we mapped the scientific literature related to activity based costing knowledge through a bibliometric analysis of the literature using quantitative analysis tools according to previous studies [50,51]. The bibliometric analysis applies statistical methods that allow us to analyse scientific performance through mapping that provides us with information such as the scientific impact evaluation (citation networks), scientific collaboration (co-authorship networks), research specialities and topics (co-occurrence networks), and knowledge flow patterns (citation networks) [52]. In particular, this method is based on transparency in data collection and the definition of the criteria for selecting documents [53].

This analysis was carried out using bibliometrix R software package (version 1.2.5042, Boston, MA, USA) written in R ecosystem [54], which joins a set of tools for exclusive processing of all the data about the publications' selected analysis [55]. This process produces different matrices [56], which are preceded by the normalisation of the publications' similarity [54].

\subsection{Data Collection (and Organisation) Procedures}

The database was collected on 1 May 2020, on the Web of Science Core Collection (WoS) and Elsevier's Scopus (SCO) databases, two of the largest and most renowned online peer-reviewed literature collections $[57,58]$. We did not apply any chronological filter, and 
we selected only 'Articles' as the document type. In the first phase, we tried a separate search for each of keyword. In both databases, we applied the following strategy: TOPIC: (activity based costing).

The collected data were downloaded in Bibtex format from Scopus. We used R Studio software (version 1.2.5042, Boston, MA, USA) to remove duplicates and create one only database file to export to bibliometrix R 3.0, and this was the package used for network analysis of the data [54]. In Figure 1, we summarize the research layout and results that led to the final set of articles.

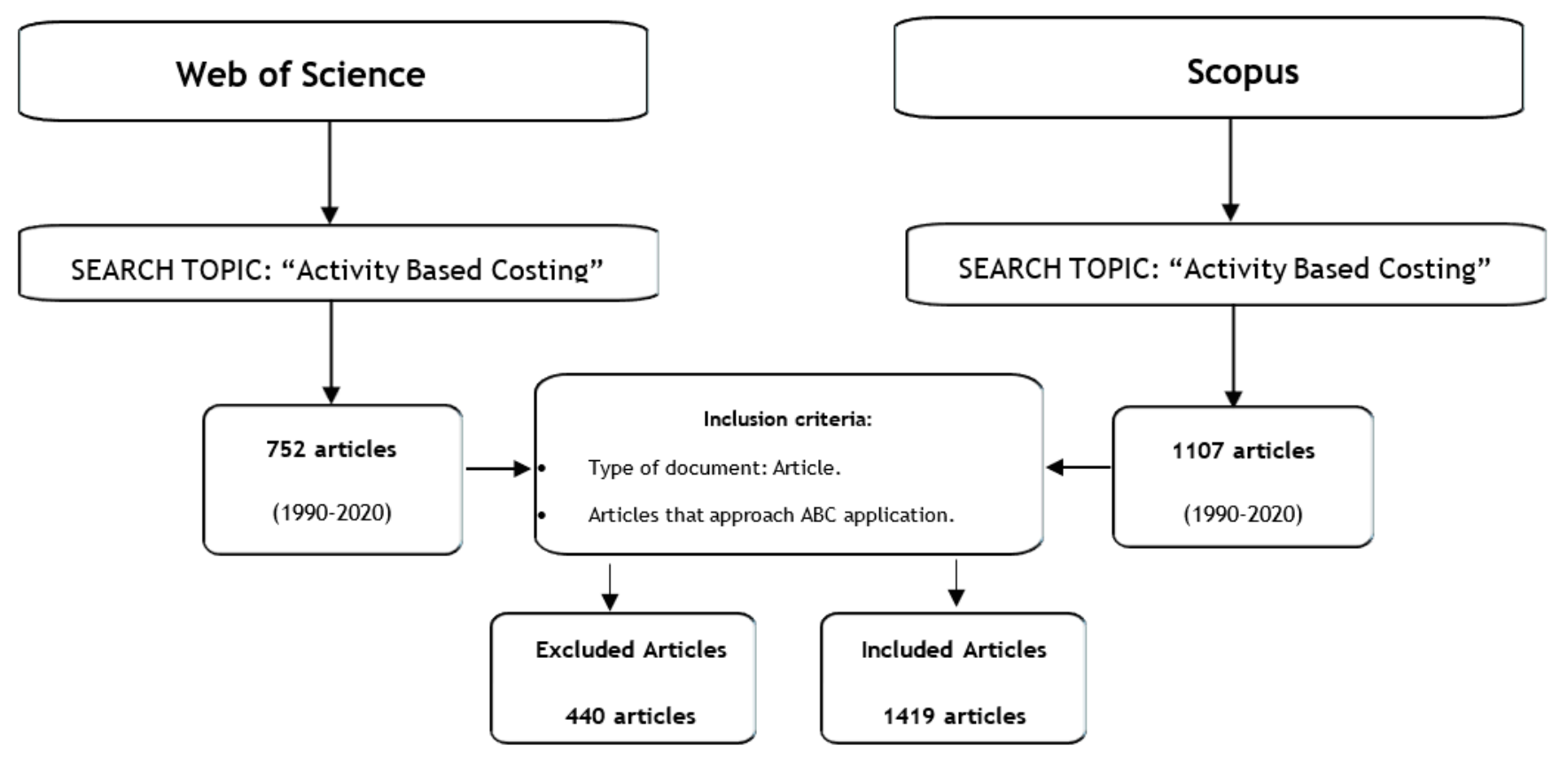

Figure 1. Search results.

The actions developed to execute the bibliometric analysis were, first, the collection of data followed by descriptive and bibliometric analyses. The literature search yielded 1859 article results, of which 440 were duplicates. Two authors reviewed and screened the titles and abstracts for inclusion and exclusion criteria. The following inclusion criteria were established: (1) type of documents: articles; (2) articles that approach the ABC application; and (3) articles mapping and reviewing the literature. To develop the analysis, bibliometrix R-Tool (version 1.2.5042, Boston, MA, USA) was used and the metadata of two databases (WoS and Scopus) was retrieved and merged [59].

The 1419 articles that were selected in WoS and Scopus were published between 1990 and 2020. After this initial screening, we excluded 440 (184 were duplicates and 256 out of inclusion criteria) abstracts and conducted the first wave of full-text review for the remaining 1419 papers. This final output was subject to a bibliometric analysis after the resolution of existing errors and inconsistencies that allowed us to homogenize the database. Each article was coded and tagged according to [60].

\subsection{Procedures Applied in Content Analyses}

Over time, the use of bibliometrics has gained growing popularity in all disciplines. We used bibliometrix $\mathrm{R}$ package for performing bibliometric analysis and building data matrices for co-citation, coupling, scientific collaboration analysis, and co-word analysis. The use of bibliometrics is gradually extending to all disciplines and is suitable for science mapping when the emphasis on empirical contributions produces voluminous, fragmented, and controversial research streams [54].

For network matrix creation, we used the bibliometrix R package. According to Aria and Cuccurullo [54], the existence of powerful, practical statistical algorithms, access to 
high-quality numerical routines, and integrated data visualisation tools are perhaps the most vital qualities to prefer $\mathrm{R}$ to other languages for scientific computation. Then, all abstracts, literature reviews, and final considerations were read, and a document was created to contain the most relevant information extracted from those sections of each article. Finally, the contents were divided according to the main constructs in order to create a text that could explain the main theoretical approaches for each cluster and the conclusions that had been drawn.

In order to create the network of collaboration between themes, institutions, and authors, we used the bibliometrix $R$ package through biblioshiny (a shiny app providing a web-interface for bibliometrix). The network analysis was made for all databases collected. We used specific and previously tested criteria for the elaboration of the outputs, namely, the number of nodes and Min edges. The scientific collaboration network is a network where nodes are authors and links are co-authorships and is one of the most well-documented forms of scientific collaboration $[54,61]$.

\section{Results}

The bibliometric analysis carried out on the publications in which the $\mathrm{ABC}$ method was approached led us to carry out a general mapping of the published literature in the most relevant databases (WoS and Scopus) of scientific production. In this sense, we obtained results on the global research performance of the authors over time, highlighted the pioneering publications every five years, analysed the general evolution, and by the author of the publications over time, we highlighted the main research themes and countries where studies had been carried out. On the other hand, we also highlighted the collaborative network between institutions, authors, and countries over time.

These results allow future researchers, by reading this article, to have a starting point in future investigations related to the application of the $A B C$ method.

This review's main contribution and mapping of the literature is now a clear chart detailing already published in this knowledge field. We identified the most essential and relevant data produced about this theme, detailing the topics that have triggered the most significant academic interest level and providing details about the academic context's ABC method application.

\subsection{Activity Based Costing Global Research Performance}

\subsubsection{Database Description}

Table 1 shows the final database sample about $A B C$ articles published in high-impact journals. A total of 1419 articles were produced by 2865 authors and a 2.67 co-authorship mean per document.

Table 1. Database description.

\begin{tabular}{|c|c|c|c|}
\hline Description & \multirow{2}{*}{ Results } & Description & \multirow{2}{*}{ Results } \\
\hline Main Information about Data & & Main Information about Data & \\
\hline Timespan & 1990-2020 & Authors & \\
\hline Sources (Journals) & 904 & Authors & 2865 \\
\hline Average years from publication & 11.7 & Author Appearances & 3791 \\
\hline Average citations per documents & 5.376 & $\begin{array}{l}\text { Authors of single-authored } \\
\text { documents }\end{array}$ & 229 \\
\hline Average citations per year per doc & 0.43 & $\begin{array}{l}\text { Authors of multi-authored } \\
\text { documents }\end{array}$ & 2636 \\
\hline References & 13,819 & Authors Collaboration & \\
\hline Document Types & & Single-authored documents & 276 \\
\hline Article & 1419 & Documents per Author & 0.495 \\
\hline Document Contents & & Authors per Document & 2.02 \\
\hline Keywords Plus (ID) & 748 & Co-Authors per Documents & 2.67 \\
\hline Author's Keywords (DE) & 3440 & Collaboration Index & 2.31 \\
\hline
\end{tabular}




\subsubsection{Publications Every Five Years}

Figure 2 represents the most cited article published about $A B C$ every five years in $A B C$. By reading the figure, we can see that the first indexed scientific work was "Time-Driven Activity-Based Costing" being published in the journal Manufacturing Systems. Five years later, the article "Application of Activity Based Costing ABC for a Peruvian NGO healthcare provider" was published in the International Journal of Health Planning and Management. Later, in 2000, the article "A framework of production planning and control with carbon tax under industry $40^{\prime \prime}$ was published in the International Journal of Production Economics. The five-year production continued to be produced the article "Activity-Based Costing for small manufacturers a field study" in the Journal of Cleaner Production. In 2010, the first article on this area of knowledge was the "Economic analysis of polca system design via simulation a multicell manufacturing case study" in the journal Transfusion. In 2015, the article "Competitiveness through cost management" was in the journal Mbio. Finally, the first article on this area to be published in 2020 was "Assessing criticality of construction materials for prioritizing their procurement using anptopsis" in the International Journal of Construction Management.

This result reflects the importance of $A B C$ 's application in organisations of different sizes and sectors, namely, in healthcare organisations and small business enterprises. The results also reflect the interest in TDABC. Several authors found that the ABC model obtained very low utilisation rates and did not last in the long run. As such, Kaplan and Anderson [22] developed the TDABC system to overcome the disadvantages pointed out to the ABC model. Thus, TDABC provides organisations with an 'elegant' and practical option to determine the cost and capacity used in processes, the profitability of products and customers through a simple, cheap, and much more powerful model than $\mathrm{ABC}$. The main focus of TDABC is to facilitate and simplify the general implementation of the system, gaining flexibility in modifying the model whenever necessary. This new approach directly allocates resources to cost objects, requiring only two sets of estimates for each group of resources, for which it is only necessary, first, to calculate the cost of providing resources, and second, to estimate the time required to execute a transaction unit for each activity.

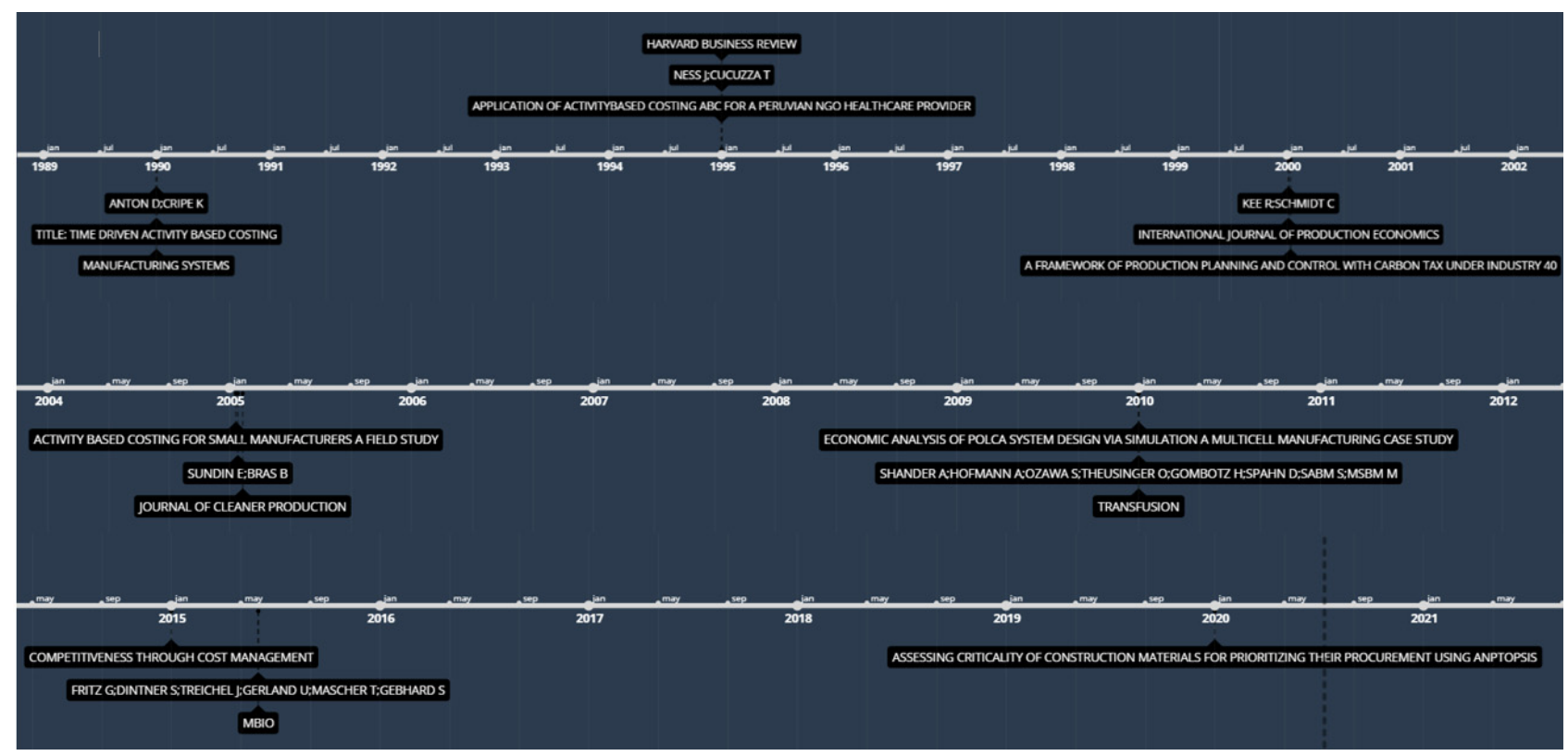

Figure 2. Most cited publications every five years. 


\subsubsection{Annual Scientific Production}

Considering the research domain, Table 2 reveals that the ABC topic emerged in 1990 with two publications and reached its peak in 2011. The best top five publication years were 2011 with 86 articles, 2008 with 82 articles, 2016 with 73 articles, 2010 with 72 articles, and 2017 with 68 articles. We found that the year with the most citations was 2010 with 856 citations, followed by 2008 with 623, 2017 with 203, 2011 with 190, and 2016 with 127 citations.

This result may be related to globalisation, internationalisation, the increase in products offered, the advancement of technology, competitiveness between companies, and above all, the need for credible and timely information by managers. With technological development and productivity improvements, a sharp reduction in direct costs is due to the replacement of human labour by machines, although this increased indirect costs and the need to develop management accounting tools to affect those costs.

Table 2. Publications per year of the source paper by ABC domain.

\begin{tabular}{cccc}
\hline Years & Total Articles & Years & Total Articles \\
\hline 1990 & 2 & 2006 & 45 \\
1991 & 2 & 2007 & 64 \\
1992 & 13 & 2008 & 82 \\
1993 & 12 & 2009 & 64 \\
1994 & 28 & 2010 & 72 \\
1995 & 24 & 2011 & 86 \\
1996 & 38 & 2012 & 58 \\
1997 & 29 & 2013 & 61 \\
1998 & 53 & 2014 & 61 \\
1999 & 29 & 2015 & 57 \\
2000 & 31 & 2016 & 73 \\
2001 & 42 & 2017 & 68 \\
2003 & 33 & 2018 & 58 \\
2004 & 44 & 2019 & 67 \\
\end{tabular}

\subsubsection{Authors Production over Time}

In Figure 3, we can observe the production obtained by the principal authors of our database over time. Each circle corresponds to a certain number of documents and the respective average of citations. In this sense, authors who have circles in their line have published at least one article on the subject under analysis-the larger the circle, the more publications the authors had that year. The greater distance between circles on the straight line means a more extended time has passed without the author publishing any article in the area of knowledge under study. As an example, we can see Tsai W. in the first rank with 16 publications from 1996 to 2019, in second place we see Mitchell F. with seven publications from 1994 to 2008, and finally, in third place, we have Afonso P., Lievens Y., and Needy K. with six publications each.

\subsubsection{Three Fields Plot}

The Sankey diagram enables one to view the main items of the three fields plot and how they are related. In the three fields plot below, we can see networking between authors, their respective countries, and research areas. The most cited authors are Tsai, Mitchell, Afonso, Lievens, and Needy, with connections to several countries like USA, China, Taiwan, and the United Kingdom. Regarding the areas most approached as an investigation object, we have $\mathrm{ABC}$ leading, followed by cost accounting, costs, and management (Figure 4). 


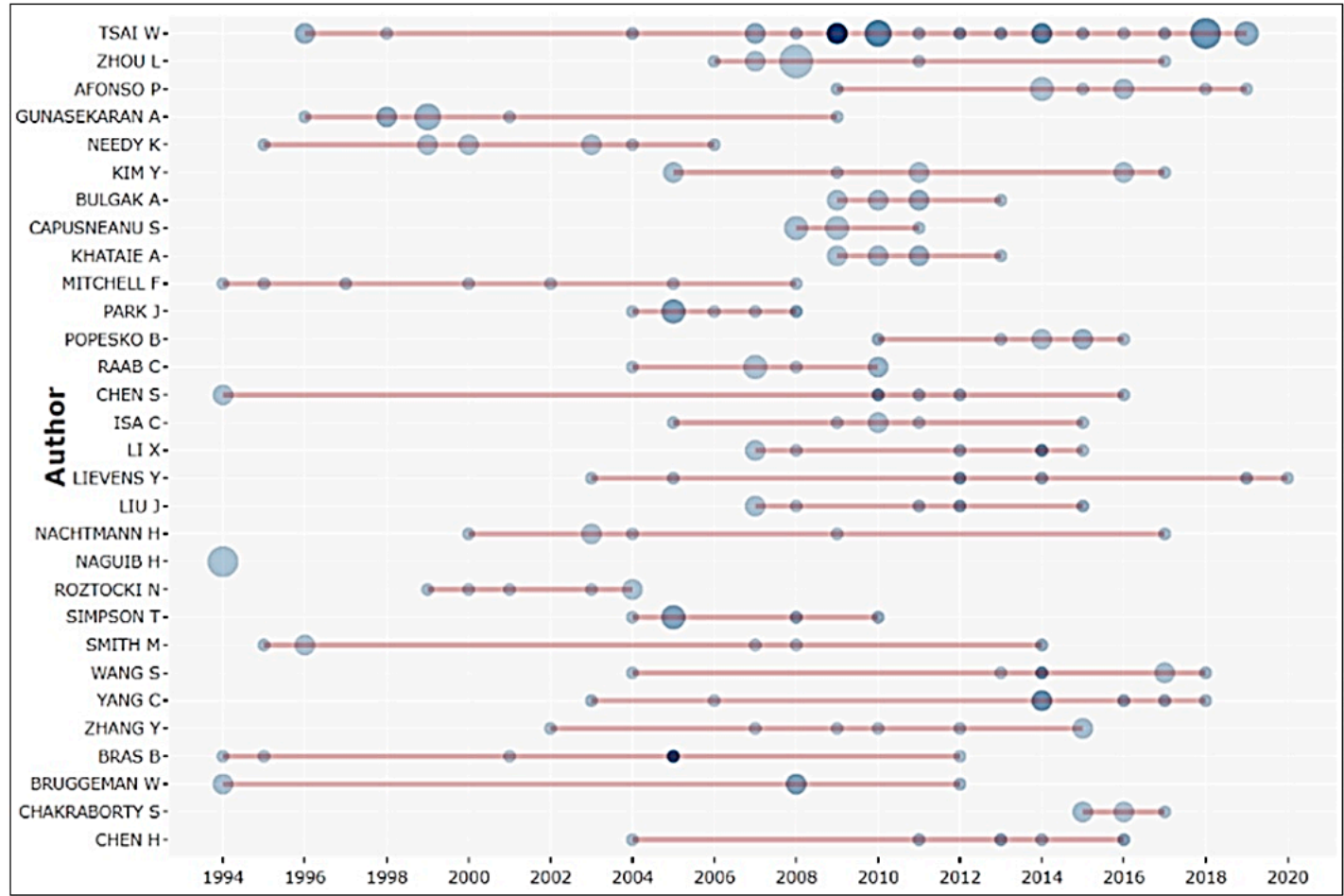

Figure 3. Authors production over Time in ABC domain.

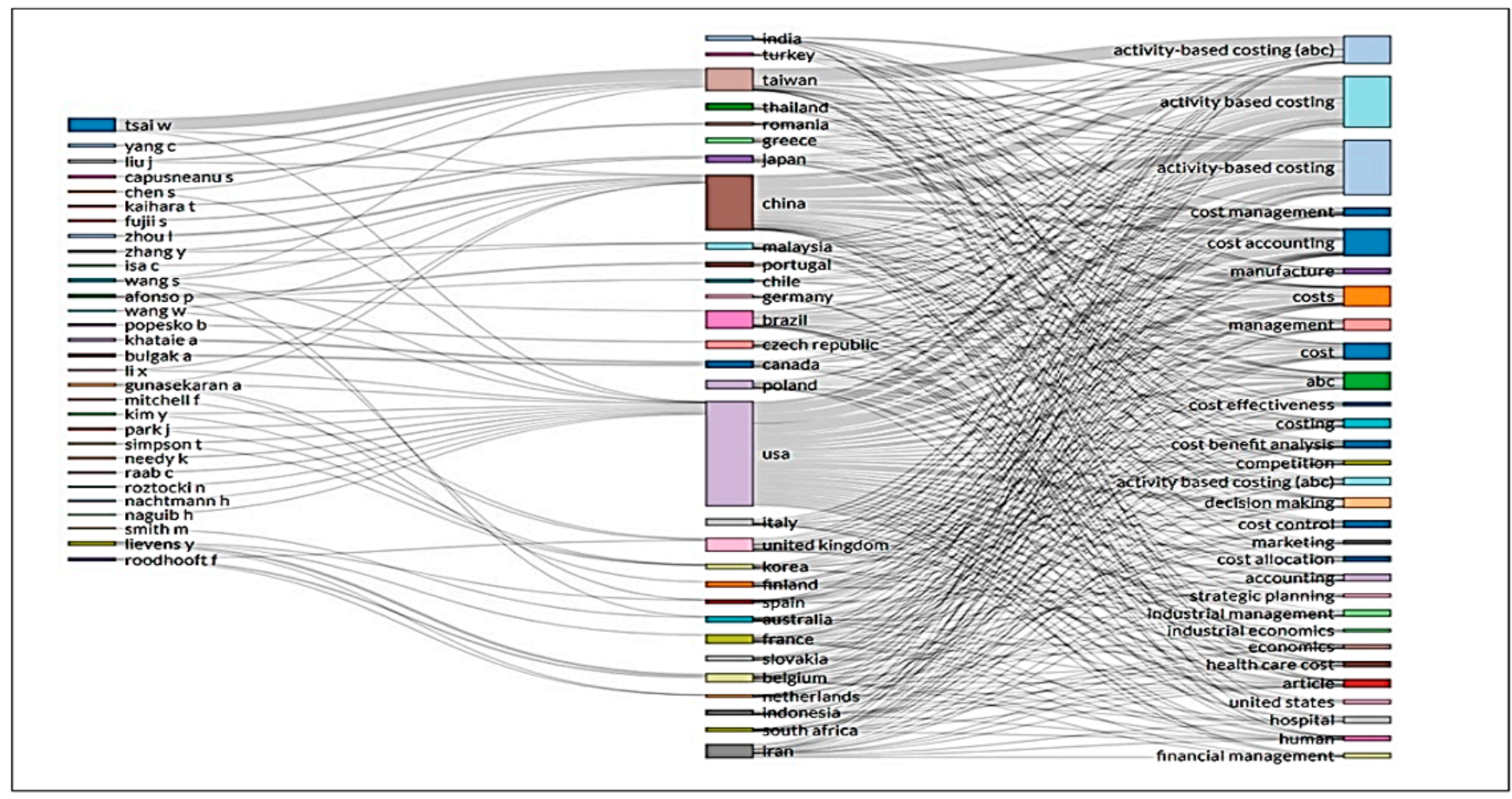

Figure 4. Three fields plot by authors, countries, and research areas.

\subsubsection{Institutions Cooperation}

Figure 5 shows the collaborative networks between the various institutions to which the most relevant authors belong. We verified the top three (previously mentioned). However, in this case, we can visualise the most direct collaborative networks of the top three through the nodes and edges that the scheme indicates to us. An edge (or link) of a network (or graph) is one of the connections between the nodes (or vertices) of the network. 
In this network, we can easily see that other universities are connected, collaboratively, with the National Central University. However, we have to highlight that the thicker the edges are, the more intense the collaboration, e.g., the National Central University networks with several universities; however, the intensity of collaboration is homogenous, except with the Chinese Culture University. The same happened with the Universidade Federal de Minas Gerais, and the Universidade Federal do Rio de Janeiro. Another similar collaboration can be identified between Katholieke Universiteit Leuven and Tilburg University. We cannot see other networks between the remaining institutions of this database.

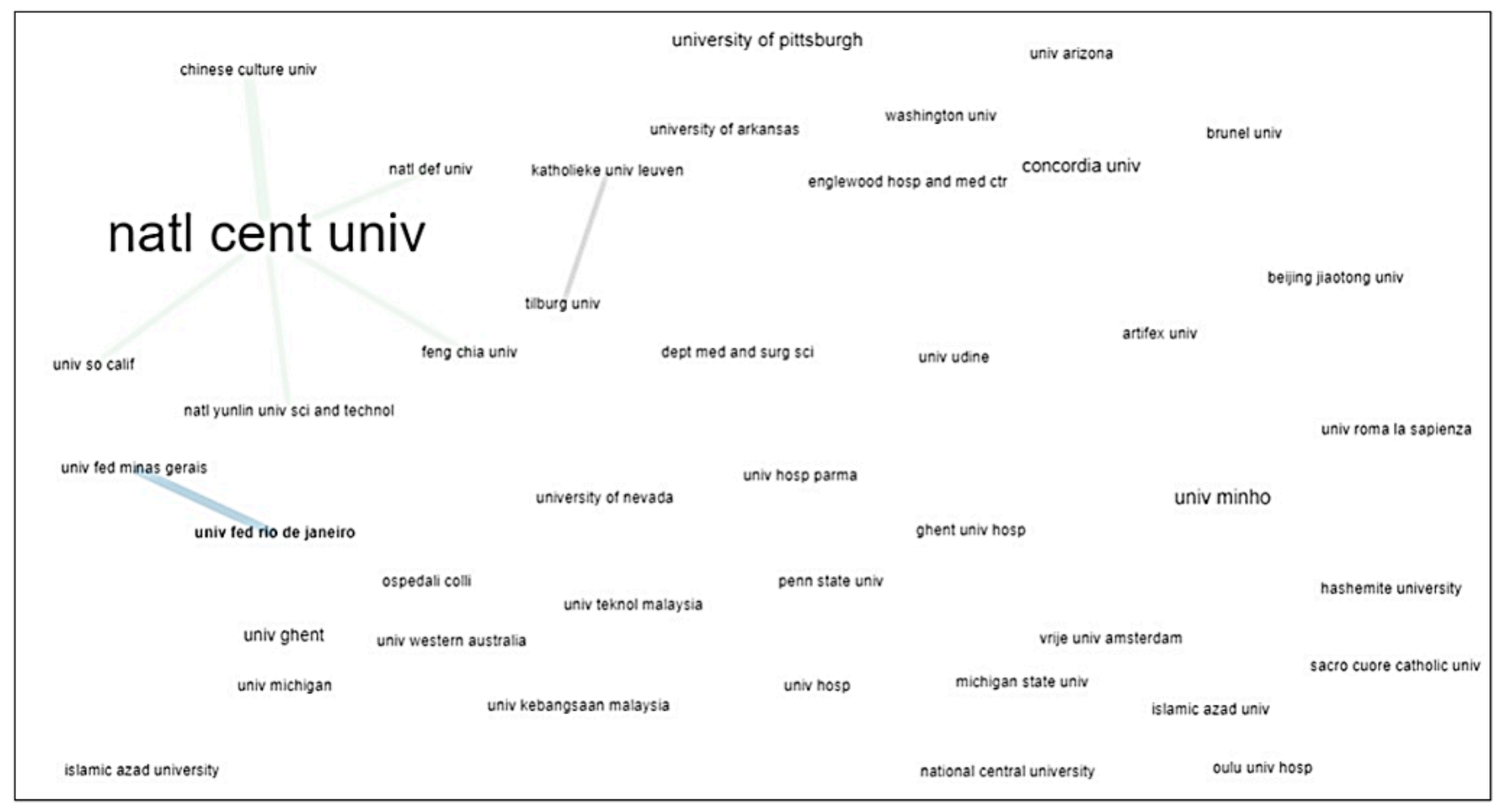

Figure 5. Collaborative networks between institutions.

It is very important to increase the institutions' cooperation to develop more investigation in this area in different contexts and cultures, stressing the determinant factors of $\mathrm{ABC}$ implementation in public and private organisations.

\subsubsection{Network Research by Authors}

Figure 6 shows the authors' network. The most prominent author is Tsai W. with a network concentrated on four directed edges (links): the one with Hsu J. from the National Central University, Jhongli is the most expressive connection, the second with Chen $\mathrm{H}$. from the National Taiwan University, the third with Liu J. from Inner Mongolia University of Technology, and finally, the fourth with Chen S. from Xerox Microelectronics Center, USA. The direct link that Tsai W. maintained with Chen S. leads to another connection emerging with Naguib H. from Xerox Microelectronics Center, USA.

\subsubsection{Network Research by Countries}

Figure 7 shows the countries network. The most prominent country is the USA with a network concentrated in seven directed edges (links), the strongest with China and then with the United Kingdom, Canada, Switzerland, Taiwan, the Netherlands, and Belgium. The second most prominent country is United Kingdom with a network concentrated on six directed edges (links), the strongest with the USA and then with New Zealand, Canada, Australia, Denmark, and Finland. The third most prominent country is the Netherlands with a direct link with Belgium and then France. The fourth prominent country is Portugal 
with a direct link with Colombia and Chile. Other countries still work without networks in this area of knowledge.

natl yunlin univ sci and technol

univ so calif

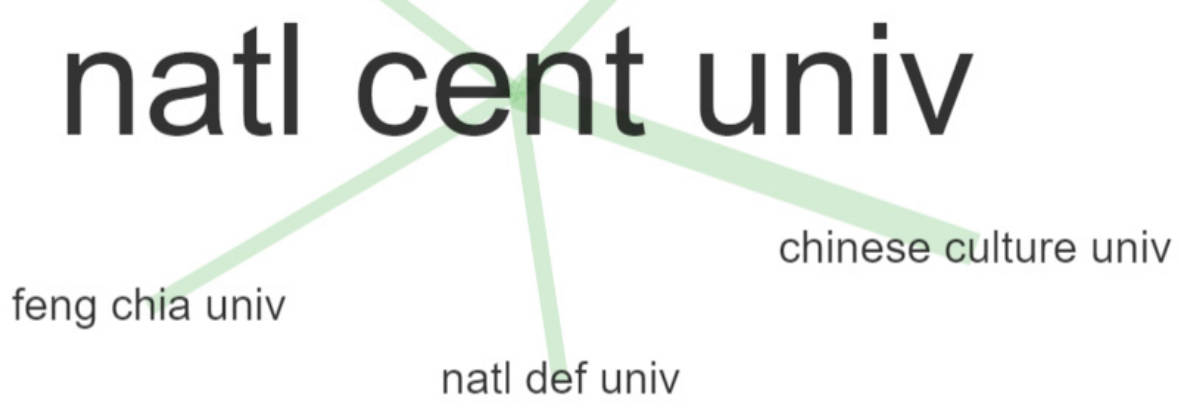

univ fed minas gerais

university of arkansas

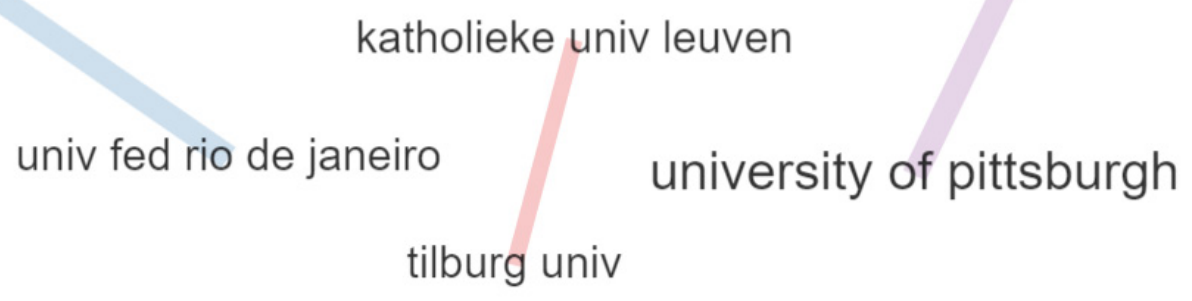

Figure 6. Authors network.

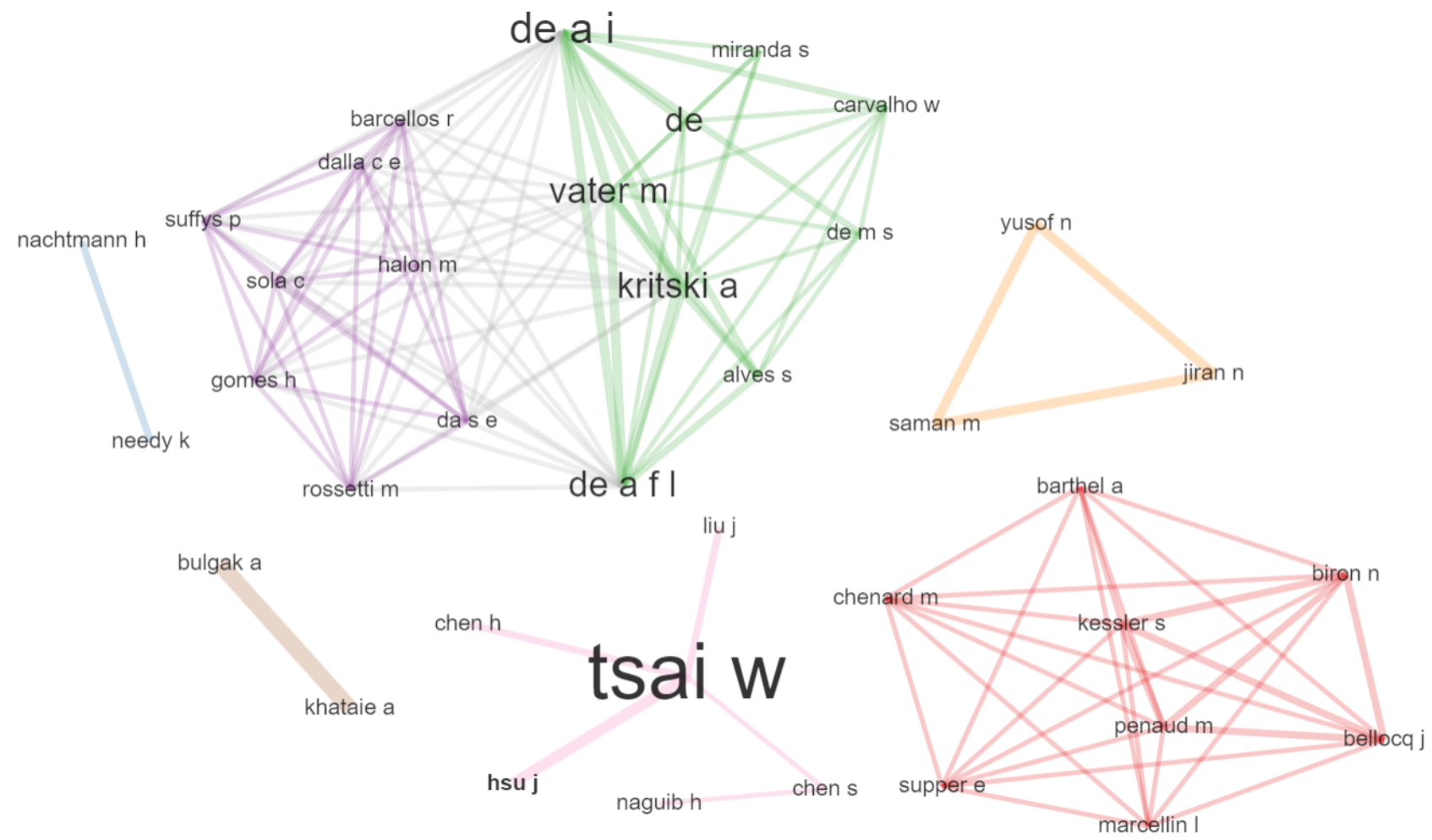

Figure 7. Countries network. 


\section{Discussion: The ABC and Open Innovation}

The relationship between $\mathrm{ABC}$ and innovation management models is a fundamental aspect nowadays where changes are permanent, and collaboration between people and entities is extremely important in identifying activities that add or do not add value to the organisation. The so-called open innovation, a concept popularized in 2003 by Henry Chesbrough in the book Open Innovation: The new imperative for creating and profiting from technology, which was based precisely on the collaboration between people and entities external to the organisation and used the benchmarking technique, helps us identify a relationship between the two concepts.

Chenhall and Moers [62] revealed that the design of management control systems has developed in response to organisations' need to address the challenges of operating in uncertain settings by embracing innovation. Rajagukguk [63] pointed out that management accounting and control systems are a useful framework to link technical decisions to economic outcomes and convert innovation potential into economic value.

For Chesbrough [64], open innovation means that valuable ideas can come from inside or outside the company and reach the market. In reality, the idea of openness supposes breaking with the traditional philosophy of not revealing internal knowledge issues to the outside, recognizing the opportunity to obtain competitive advantages through relationships with professionals and external organisations, sharing resources and knowledge, and establishing alliances and partnerships. Through a broader analysis, the objective is to accelerate internal innovation and expand markets for the external use of innovation, influencing organisational results, 'open innovation needed to combine internal research with external ideas and then deploy those ideas both within their systems and also through other companies' systems. The key for these firms is to figure out what necessary missing pieces should be internally supplied and how to integrate both internal and external pieces into systems and architectures' [63] (p. 81).

Higher education institutions have already implemented, in many cases, departments that are dedicated to establishing cooperation between companies and transferring technology. In fact, the need to develop innovations in terms of processes and products is increasingly important, with $\mathrm{ABC}$ playing a fundamental role in defending the improvement of processes and the more precise allocation of costs to activities and products as an essential factor for the long-term companies' survival.

Open innovation leads us to the search for external sources of ideas in addition to the internal flows of knowledge, contrary to the traditional model of vertical integration, in order to increase the innovation process, having the advantage of the appearance of new ideas and technologies, conducting strategic research, and providing the possibility of extending and/or diversifying the business [65]. For Trentini et al. [66], open innovation, despite being a new model of innovation management, shows itself as a viable alternative for maintaining and expanding knowledge by capturing value and sustaining business, highlighting the acceleration in launch time and commercialisation of products, using external knowledge, and economically exploiting projects not developed by companies.

The $A B C$ and the concept of open innovation bear on the philosophy of continuous improvement and optimisation of processes to improve its execution in the vectors in which the organisation works or can work. In this sense, according to Chesbrough [64], we have to analyse how to improve the products and processes innovatively from inside the organisation and understand what the external environment wants us to improve. Although $\mathrm{ABC}$ is an internal concept for the top management and employees because it is a costing system, it is important to know the intentions and trends of all ecosystems that surround the organisation, highlighting the role of suppliers and customers (current and potential) and society in general, which defines a set of operating standards.

For James [67], the ABC system defines products and product batches, consumers, suppliers, distribution channels, and market segments as cost objects. Therefore, it is being noted that management accounting systems, such as $A B C$, can help companies make more effective production decisions by providing more accurate cost information leading 
to increased profitability. The author considers the importance of adopting these new or advanced management accounting techniques touted as relevant to companies that take a more strategic focus to business and thus were more effective in responding to global competitiveness. However, Biancone et al. [68] pointed out that the ABC system and TDABC do not explain how to manage innovation. According to Alvarez-Aros and Herrera [69], innovation explains economic levels, the development of nations, and business performance; in the latter, the paradigm of open innovation is not the exception.

Studies on the impact of open innovation on organisational performance have seen an increase in recent years [68-76]. Moretti e Biancardi [71] sought to sort the impact of the level of inbound openness derived by the amount invested in internal development versus the external acquisition of intangible assets on the firm's performance according to three dimensions-economic performance, measured as the amount of firm turnover; the firm's financial performance, measured with shares value; and human resources performance, measured as the level of employment. Results show that the effects of both internal development and external acquisition are positive and significant across different dimensions. Zhang et al. [73] studied how human capital can affect the relationship between open innovation and firms' financial performance. In the study of Alvarez-Aros and Herrera [69], the main results reveal the use of the inbound, outbound, and mixed open innovation strategy. The study of Silva and Dacorso [77] analysed the model of open innovation in the context of micro and small enterprises, showing evidence of how this new way to innovate, based on the search for external knowledge as the basis for innovation, can generate competitive advantage and denote an alternative for the development of these companies. Askarany et al. [78] analysed the factors that influence ABC's adoption by assessing the contribution of innovation characteristics on adoption. The results reveal that organisations are more likely to adopt $A B C$ when they attach a high level of importance to innovations' relative advantages.

Rajagukguk [63] argued that the use of management accounting and control systems in open innovation can articulate the value proposition, identify a market segment, define the structure of the firm's value chain, specify the revenue generation mechanism for the firm, and estimate the cost structure and target margins of producing the offering, given the value proposition and value chain structure chosen to other firms or through launching new ventures that exploit the technology in new business arenas.

According to Bigliardi et al. [70] (p. 2), to implement an open innovation strategy, 'it is necessary for companies to carry out innovation activities-the selling and purchasing of licenses and patents, and the exploitation of intellectual capacity-in order to transform the creation of value into the optimum combination of internal and external resources. Most of the literature has revealed the positive effect of a firm's application of open innovation activities on its innovation performance. Indeed, an increase in the interactions a company has with other organisations generates greater access to new ideas, skills, technologies and other intangible assets, as well as enhanced possibilities to innovate with success'.

Kwasnicki [79] described an evolutionary model of industrial dynamics and reported on the simulation study of the model, considering the cost regime, the technical performance regime, and the capital productivity regime. The author also investigated the influence of the different types of innovation on the development of the industry, particularly on industry concentration and on the products' price distribution, and analysed the evolution of industry structure with the possibility of firm entry.

Yun et al. [80] studied the structure and mechanism of modern capital economic dynamics that motivate the growth limits of capitalism. They concluded that when there is low balance among the market for open innovation by small and medium enterprises and start-ups, closed open innovation by big business, and social open innovation, the economic dynamics decrease, and the economic growth rate slows down to nearly zero or even negative. When there is a medium balance among these three sub-economies, the economic dynamics increase, and the economic growth rate will be maintained at a high 
level, and when there is a high balance among the three sub-economies, the economic dynamics become too low, and the economic growth rate stays at a low level.

The study of Yun and Liu [81] explored how sustainability can be achieved through open innovation in the current fourth industrial revolution. The authors identified microand macro-dynamics of open innovation, in addition to the dynamic roles of industry, government, university, and society, and proposed a conceptual framework to understand open innovation of micro- and macro-dynamics with a quadruple-helix model for social, environmental, economic, cultural, policy, and knowledge sustainability. They argued that 'the industry continuously adopts open platforms to create and maintain ecosystem innovation. The government's role has changed from regulation control toward facilitation. Universities have become proactively engaged in multiple areas, from technology transfer to knowledge co-creation. Societies and customers have started to form new concepts, $R \& D$, and commercialisation, resulting in a shared economy'.

Yun et al. [82] discussed dynamics and differences of business models in the carsharing industry and focussed on open innovation as the trigger of diverse business models. They concluded that 'business models of the car-sharing firms Uber, DiDi-Chuxing, and KakaoT are not fixed but rather are dynamically changing. Second, business models of carsharing firms are the result of interaction with government regulations, the taxi industry, public transportation, and the automotive car industry. Third, open innovation strategies of car-sharing firms determine the contents and dynamics of car-sharing business models, such as the revenue business model, responsibility business model, and system business model upon interaction with four agencies'.

In another study, Yun et al. [83] presented the case of Alibaba, especially the application of global, creative e-commerce business models through open innovation in a short time. The company has overcome complexity through an open innovation-friendly culture and undergone the expansion of its open business model feedback loop platform.

Yun et al. [84] studied what kind of open innovation channels exist, and how can these channels operate as a knowledge funnel to conquer the growth limit of capitalism in the fourth industrial revolution. The authors defended additional field researches on each open innovation engineering channel in addition to research on finding out more open innovation engineering channels are required.

Zhu et al. [85] analysed the impact of the interplay between different open innovation implementations and business models on the speed of the firms' new product development (NPD). They found that in Chinese firms, open innovation breadth and open innovation depth positively affect NPD speed. The results also demonstrate that an efficient business model strengthens the positive effect of open innovation depth, while weakening the positive effect of open innovation breadth.

Spithoven et al. [86] (p. 131) argued that 'the ability to absorb external knowledge has become a major driver for competition'. Their study focussed on the role of collective research centres in building absorptive capacity at the inter-organisational level and concluded that the openness of the innovation process forces firms lacking the absorptive capacity to search for alternative ways to engage in inbound open innovation.

In short, globalisation and internationalisation impose innovation and adequate costing systems to obtain sustainable competitive advantages, increasingly focussed on the use of internal and external resources, for more excellent knowledge of the environment and strengthening of knowledge through external links [69]. The rising costs of technology development and the decrease in the life cycle of products changed the way of doing business and proposed a new competition format. Nevertheless, innovation costs can be reduced by sharing knowledge, risks, and entering new distribution channels resulting from the open innovation model [77]. 


\section{Conclusions}

In the current scenario in which companies are inserted, countless obstacles can jeopardize their social sustainability; in other words, obtaining profit. In this sense, the implementation of an adequate costing method which highlights the expenses incurred for producing a product or provision of a service and guarantees timely responses enables the formation of more reasonable and competitive prices in the market.

$\mathrm{ABC}$ is recognised as a management tool that allows greater control in the production process, highlights the factors that cause costs, contributes to the reduction of costs in a given activity, or even its elimination, and assists managers in the arduous decision process making. Thus, in the last decades, the ABC system was used because it is a method that aims to reduce distortions in the determination of the cost of products, being practically useful in organisations with diversified production and those that present very high indirect costs in the total cost structure. It appears as a tool capable of responding to the limitations pointed out by traditional costing systems when allocating indirect costs to products, and it is based on the fact that products consume activities and that they consume resources.

The presented study had the main objective of analysing the international publications on the costing system based on recent years' activities and identifying trends of evolution and future research opportunities. In this study, we contributed to the evolution of knowledge because we realised the existence of a gap in research related to the fact that the most recent investigation in which a literature review about $A B C$ method was carried out also addressed, simultaneously, the TDABC [87]. The last literature review carried out only on the $A B C$ method was carried out in 2010 [88], so this study is particularly relevant to fill this gap.

The methodology adopted to carry out this study was a literature review and mapping, selecting the relevant publications in the study area from the ISI Web of Science (WoS) and Scopus databases. This research project carried out the mapping and description of the literature correspondingly set out in terms of publication distribution per year, most productive authors, top manuscripts per citations, manuscripts co-citations network, total citations per country, corresponding authors' countries, corresponding authors' network, most relevant keywords, and finally, the most relevant keywords network.

Furthermore, the study concludes that this theme continues to stimulate high levels of interest in researchers, with recent years seeing rising numbers of research projects in this field [89-91]. Hence, mapping the literature led to providing a general vision about what has been researched thus far within the $\mathrm{ABC}$ application.

Having defined the research protocol and the criteria adopted for inclusion and exclusion, our final database searches returned a total of 1419 articles spanning a timeframe ranging from 1990 to 2020 that were then subject to analysis and mapping. The result of this thorough analytical process was the production of bibliometric analysis, following their respective levels of academic importance resulting from summing up their WoS and Scopus citations [92]. In parallel, and as the research theme so required, we also undertook the mapping of $A B C$ application to the specific field of management irrespective of the number of citations.

We immediately noticed that there had been a substantial increase in publications over the years, which was motivated by the growing interest in this area of Knowledge [87] by authors from large higher education institutions with experience in this knowledge area [3].

The vast majority of studies in this area have been done in the USA in the first place, with China in the second and the United Kingdom in the third. With regard to the general conclusions from mapping the literature, we may state that $\mathrm{ABC}$ is increasingly the object of scientific study and represents an area with excellent research potential that necessarily has to evolve because various limitations to the studies still exist, many of them lacking both in robustness and in the capacity for extrapolation to a broader reality [93].

This study systematically reviewed papers about ABC, extracted from the Web of Science and Scopus databases, using two bibliometric analyses-mapping analysis and 
bibliographic coupling using the software VOSviewer and bibliometrix R package. This original study gave the possibility to systematise the literature about $A B C$ and its application, besides helping fill the gap regarding the need to synthesise this critical knowledge area, contributing to various studies in this field, and paving the way for further research.

This review and mapping of the literature, which was concerned with $\mathrm{ABC}$ effectiveness in higher education, are very interesting to future studies in this scope because we can see, in the main paper findings, the most important information about this area of knowledge answered questions such as what, where, when, who, and how, for which this research has been conducted around the academic world.

The main limitations of the study carried out include the fact that only the Web of Science and Scopus databases were used and the filters that were used (period, specific categories, only empirical articles, not considering books, master's dissertations, theses of doctorate, presentations at congresses/conferences or working papers). Besides, it is essential to mention that we only searched for articles with the expression 'activity based casting' or ' $\mathrm{ABC}$ ' on the topic. There may be other articles, equally relevant, that address the issue without being explicit in the respective topic. We should also mention the fact that some relevant articles were not considered because they were not in the analysed database and the fact that we focussed specifically on $\mathrm{ABC}$, omitting other relevant or similar costing and management systems, namely, activity-based management (ABM) and TDABC.

As in the study by Stefano et al. [19], we believe that this work contributes to foster discussions in the academic and business world on this theme, insofar as the survival of organisations depends on their ability to generate profits, which, in turn, depends on a well-structured costing system according to the organisation's needs to support coherent decision making and efficient cost management.

For future investigations, other keywords may be included in the research or the search can be expanded to other sources, such as books and book chapters, articles published in other magazines, communications presented at congresses/conferences and monographs, theses and dissertations, and data (for example, ScienceDirect) to expand the verification of the elements studied here and consolidate the trends inherent in this area. We can also analyse other variables, such as, for example, the most relevant trend topics, the primary methods used, and most relevant theories to conduct research and analyse results (for example, institutional theory, theory of constraints, theory of agency; theory of contingency, etc.).

Finally, we believe that it would be useful to obtain more knowledge about the benefits and critical aspects associated with the use of $\mathrm{ABC}$, which would be of particular interest to professionals who deal with the implementation of $\mathrm{ABC}$ in practice.

Author Contributions: Conceptualisation, P.Q. and R.S.; methodology, R.S.; software, R.S.; validation, P.Q. and R.S.; formal analysis, P.Q. and R.S.; investigation, P.Q. and R.S.; writing-original draft preparation, P.Q.; writing —review and editing, P.Q. and R.S.; visualisation, R.S.; supervision, P.Q.; project administration, P.Q. and R.S.; funding acquisition, P.Q. and R.S. All authors have read and agreed to the published version of the manuscript.

Funding: The work of the author Rui Silva is supported by national funds, through the FCTPortuguese Foundation for Science and Technology under the project UIDB/04011/2020. The work of the author Patrícia Quesado is financed by national funds through FCT-Foundation for Science and Technology, I.P., within the scope of multi-annual funding UIDB/04043/2020.

Institutional Review Board Statement: Not applicable.

Informed Consent Statement: Informed consent was obtained from all subjects involved in the study.

Data Availability Statement: Not applicable.

Acknowledgments: The authors gratefully acknowledge the Polytechnic Institute of Cávado and Ave (School of Management) and CICF (Research Centre on Accounting and Taxation), and University of Trás-os-Montes and Alto Douro and CETRAD (Centre for Transdisciplinary Development Studies).

Conflicts of Interest: The authors declare no conflict of interest. 


\section{References}

1. Zanievicz, M.; Beuren, I.; Santos, P.; Kloeppel, N. Métodos de Custeio: Uma meta-análise dos artigos apresentados no Congresso Brasileiro de Custos no período 1994-2010. Rev. Bras. Gestão Negócios 2013, 15, 601-616.

2. Zimmerman, J. Conjectures regarding empirical managerial accounting research. J. Acc. Econ. 2001, 32, 411-427. [CrossRef]

3. Altawati, N.; Kim-Soon, N.; Ahmad, A.; Elmabrok, A. A Review of Traditional Cost System versus Activity Based Costing Approaches. Adv. Sci. Lett. 2018, 24, 4688-4694. [CrossRef]

4. Akyol, D.; Tuncel, G.; Bayhan, G. A comparative analysis of activity-based costing and traditional costing. Int. J. Ind. Manuf. Eng. 2005, 1, 136-139.

5. Balakrishnan, R.; Labro, E.; Sivaramakrishnan, K. Product cost as decision aids: An analysis of alternative approaches (part 1). Account. Horiz. 2012, 26, 1-20. [CrossRef]

6. Balakrishnan, R.; Labro, E.; Sivaramakrishnan, K. Product cost as decision aids: An analysis of alternative approaches (part 2). Account. Horiz. 2012, 26, 21-41. [CrossRef]

7. Cooper, R.; Kaplan, R. Activity-based systems: Measuring the cost of resource usage. Account. Horiz. 1992, 6, 1-13.

8. Cooper, R.; Kaplan, R. Profit priorities from activity-based costing. Harv. Bus. Rev. 1991, 69, 130-135.

9. Bužanin, I. ABC Methods-The response to the modern cost accounting. Bus. Cons. 2020, 12, 20-31.

10. Quesado, P.; Lopes, M. A implementação do sistema ABC numa empresa de fabricação de carroçarias. In Estudos de Gestão e Empreendedorismo; Matias, F., Santos, J.A.C., Afonso, C., Baptista, C., Ramos, C.M.Q., Santos, M.C., Eds.; Universidade do Algarve: Faro, Portugal, 2018; pp. 291-311.

11. Quesado, P.; Lopes, M. Benefícios e Determinantes do Sistema de Custeio Baseado nas Atividades (ABC): Um Estudo de Caso. Qual. Rev. Eletrônica 2016, 17, 37-57. [CrossRef]

12. Allain, E.; Laurin, C. Explaining implementation difficulties associated with activity-based costing through system uses. J. Appl. Account. Res. 2018, 12, 181-198. [CrossRef]

13. Pike, R.; Tayles, M.; Mansor, N. Activity-based costing user satisfaction and type of system: A research note. Br. Account. Rev. 2011, 43, 65-72. [CrossRef]

14. Cooper, R. Implementing an activity-based cost system. J. Cost Manag. 1990, 4, 33-42.

15. Kapan, R. One Cost System isn't Enough. Harv. Bus. Rev. 1988, 1, 61-66.

16. Argyris, C.; Kaplan, R. Implementing New Knowledge: The Case of Activity-Based Costing. Account. Horiz. $1994,8,83-105$.

17. Park, Y.; Jung, S.; Yousef, J. Time-Driven Activity-Based Costing Systems for Marketing Decisions. Stud. Bus. Econ. 2019, 14, 191-207. [CrossRef]

18. Cooper, R.; Slagmulder, R. Strategic cost management: Expanding scope and boundaries. Cost Manag. 2003, 17, $23-30$.

19. Stefano, N.; Lisbôa, M.; Casarotto Filho, N. Activity-Based Costing: Estado da Arte Proposta pelo Pesquisador e Revisão Bibliométrica da Literatura. Iberoam. J. Proj. Manag. 2012, 3, 1-22.

20. Noreen, E. Conditions Under Which Activity-Based Cost Systems Provide Relevant Costs. J. Manag. Account. Res. 1991, 3, 159-168.

21. Cokins, G.; Hicks, D. Where does the ABC fit amongst the clutter of managerial accounting? J. Cost Manag. 2007, $21,21-28$.

22. Kaplan, R.; Anderson, S. Time-driven activity-based costing. Harv. Bus. Rev. 2004, 82, 131-138. [CrossRef] [PubMed]

23. Compton, T. Implementing activity-based costing. CPA J. 1996, 66, 20-27.

24. Major, M.; Vieira, R. Activity-Based Costing/Management. In Contabilidade e Controlo de Gestão: Teoria, Metodologia e Prática; Major, M.J., Vieira, R., Eds.; Escolar Editora: Lisboa, Portugal, 2017; pp. 297-329.

25. Khodadadzadeh, T. A state-of-art review on activity-based costing. Accounting 2015, 1, 89-94. [CrossRef]

26. Kalicanin, D. Activity-Based Costing as an information basis for an efficient Strategic Management Process. Econ. Ann. 2013, 58, 95-119. [CrossRef]

27. Arora, A.; Raju, M. A Comparative Analysis of Perceived and Actual Benefits from Implementation of Activity Based Costing in Selected Manufacturing Units in India. Rev. Prof. Manag. 2018, 16, 55-61. [CrossRef]

28. Kaplanog, V. Application of activity-based costing to a land transportation company: A case study. Int. J. Prod. Econ. 2008, 116, 308-324.

29. Haroun, A. Maintenance cost estimation: Application of activity-based costing as a fair estimate method. J. Qual. Maint. Eng. 2015, 21, 258-270. [CrossRef]

30. Al-Dhubaibi, A.A.S. Optimizing the value of activity based costing system: The role of successful implementation. Manag. Sci. Lett. 2021, 11, 179-186. [CrossRef]

31. Pietrzak, Z.; Wnuk-Pel, T.; Christauskas, C. Problems with Activity-Based Costing Implementation in Polish and Lithuanian Companies. Eng. Econ. 2020, 31, 26-38. [CrossRef]

32. Stratton, W.; Desroches, D.; Lawson, R.; Hatch, T. Activity-based costing: Is it still relevant? Manag. Account. Quart. 2009, 10, 31-40.

33. Askarany, D.; Yazdifar, H. Why ABC is Not Widely Implemented? Int. J. Bus. Res. 2007, 7, 93-98.

34. Bornia, A. Análise Gerencial de Custos em Empresas Modernas; Bookman: Porto Alegre, Brazil, 2002.

35. Fito, A.; Llobet, J.; Cuguero, N. The activity-based costing model trajectory: A path of lights and shadows. Intang. Cap. 2018, 14, 146-161. [CrossRef] 
36. Ouassini, I. An analysis of Panasonic Group in Terms of Activity- Based Costing, Just-in-time Production and Quality and Environment Costing. J. Oper. Manag. 2019, 18, 49-65. [CrossRef]

37. Gosselin, M. The effect of strategy and organizational structure on the adoption and implementation of activity-based costing. Account. Organ. Soc. 1997, 22, 105-122. [CrossRef]

38. Rankin, R. The Predictive Impact of Contextual Factors on Activity-Based Costing Adoption. J. Account. Financ. 2020, $20,66-81$.

39. Vedernikova, O.; Siguenza-Guzman, L.; Pesantez, J.; Arcentales-Carrion, R. Time-Driven Activity-Based Costing in the Assembly Industry. Australas. Account. Bus. Financ. J. 2020, 14, 3-23.

40. Stonciuviene, N.; Usaite-Duonieliene, R.; Zinkeviciene, D. Integration of Activity-Based Costing Modifications and LEAN Accounting into Full Cost Calculation. Eng. Econ. 2020, 31, 50-60. [CrossRef]

41. Wegmann, G. A typology of cost accounting practices based on activity-based costing-A strategic cost management approach Asia Pac. Manag. Account. J. 2019, 14, 161-184. [CrossRef]

42. Järvinen, J.; Väätäjä, K. Customer Profitability Analysis Using Time-Driven Activity-Based Costing: Three Interventionist Case Studies. Nord. J. Bus. Forthcom. 2018, 67, 27-47.

43. Major, M.; Hoque, Z. Activity-Based Costing: Concepts, Issues and Practice. In Handbook of Cost and Management Accounting; Hoque, Z., Ed.; Spiramus: London, UK, 2005; pp. 83-103.

44. Foster, G.; Swenson, D. Measuring the success of activity-based cost management and its determinants. J. Manag. Account. Res. 1997, 9, 109-141.

45. Aljabr, A. The influences on Activity-Based Costing adoption as an optimal costing system design: Evidence from Saudi Arabia 2020. Account. Manag. Inf. Syst. 2020, 9, 444-479.

46. Diehl, C.; Souza, M. Publicações sobre o Custeio Baseado em Atividades (ABC) em Congressos Brasileiros de Custos no período de 1997 a 2006. Contab. Vista Rev. 2008, 19, 39-57.

47. Barsanti, H.; Souza, A. Método de Custeio Baseado em Atividades: Uma Pesquisa Bibliométrica. Pensar Contábil. 2018, 20, 44-54.

48. Souza, A.; Avelar, E.; Boina, T. Custeio Baseado em Atividades: Uma Análise das Pesquisas Brasileiras Desenvolvidas na Primeira Década do Século XXI. Rev. Inf. Cont. 2016, 10, 1-19.

49. Gosselin, M. A Review of Activity-Based Costing: Technique, Implementation and Consequences. Handb. Manag. Account. Res. 2007, 2, 641-674.

50. Dabić, M.; Maley, J.; Dana, L.-P.; Novak, I.; Pellegrini, M.M.; Caputo, A. Pathways of SME internationalization: A bibliometric and systematic review. Small Bus. Econ. 2020, 55, 705-725. [CrossRef]

51. Pizzi, S.; Caputo, A.; Corvino, A.; Venturelli, A. Management research and the UN Sustainable Development Goals (SDGs): A bibliometric investigation and systematic review. J. Clean. Prod. 2020, 276, 124033. [CrossRef]

52. Ding, Y.; Yan, E.; Frazho, A.; Caverlee, J. PageRank for ranking authors in co-citation networks. J. Am. Soc. Inf. Sci. Technol. 2009, 60, 2229-2243. [CrossRef]

53. Hadengue, M.; de Marcellis-Warin, N.; Warin, T. Reverse innovation: A systematic literature review. Int. J. Emerg. Mark. 2017, 12, 142-182. [CrossRef]

54. Aria, M.; Cuccurullo, C. Bibliometrix: An R-tool for comprehensive science mapping analysis. J. Informetr. 2017, 11, 959-975. [CrossRef]

55. Dervis, H. Bibliometric Analysis using Bibliometrix an R Package. J. Sci. Res. 2019, 8, 156-160. [CrossRef]

56. Moral-Muñoz, J.A.; Herrera-Viedma, E.; Santisteban-Espejo, A.; Cobo, M.J. Software tools for conducting bibliometric analysis in science: An up-to-date review. Prof. Inf. 2020, 29, 1-20. [CrossRef]

57. Jiang, G.; Kotabe, M.; Zhang, F.; Hao, A.; Paul, J.; Wang, C. The determinants and performance of early internationalizing firms: A literature review and research agenda. Int. Bus. Rev. 2020, 29, 1-14. [CrossRef]

58. Mudarra-Fernández, A.; Carrillo-Hidalgo, I.; Pulido-Fernández, J. Factors influencing tourist expenditure by tourism typologies: A systematic review. Anatolia 2019, 30, 18-34. [CrossRef]

59. Rodriguez-Soler, R.; Uribe-Toril, J.; Valenciano, J.D.P. Worldwide trends in the scientific production on rural depopulation, a bibliometric analysis using bibliometrix R-tool. Land Use Policy 2020, 97, 104787. [CrossRef]

60. Caputo, A.; Marzi, G.; Pellegrini, M.M.; Rialti, R. Conflict management in family businesses. Int. J. Confl. Manag. 2018, 29, 519-542. [CrossRef]

61. Glänzel, W.; Schubert, A. Analyzing scientific networks through co-authorship. In Handbook of Quantitative Science and Technology Research; Springer: Berlin/Heidelberg, Germany, 2004; pp. 257-276.

62. Chenhall, R.; Moers, F. The role of innovation in the evolution of management accounting and its integration into management control. Account. Organ. Soc. 2015, 47, 1-13. [CrossRef]

63. Rajagukguk, S. Accounting Control Systems, Open Innovation and Sustainable Competitive Advantage. KnE Soc. Sci. 2018, 3 , 74-85.

64. Chesbrough, H.W. The era of open innovation. MIT Sloan Manag. Rev. 2003, 44, 35-41.

65. Chesbrough, H.W.; Vanhaverbeke, W.; West, J. Open Innovation: Researching a New Paradigm; Oxford University Press: Oxford, UK, 2006.

66. Trentini, A.; Furtado, I.; Dergint, D.; Reis, D.; Carvalho, H. Inovação Aberta e Inovação Distribuída, Modelos Diferentes de Inovação? Rev. Eletr. Eletrônica Negócios 2012, 5, 88-109. [CrossRef] 
67. James, P. The Application of Innovative Management Accounting Principles for Enhancing Profitability and Competitiveness: An Exploratory Study of Jamaican Manufacturers. Int. J. Bus. Soc. Res. 2012, 2, 47-60.

68. Biancone, P.; Secinaro, S.; Brescia, V.; Calandra, D. Management of Open Innovation in Healthcare for Cost Accounting Using HER. J. Open Innov. Technol. Mark. Complex. 2019, 5, 1-16.

69. Alvarez-Aros, E.; Herrera, M. Estrategias y Prácticas de la Innovación Abierta en el Rendimiento Empresarial: Una Revisión y Análisis Bibliométrico. Investig. Adm. 2018, 47, 121.

70. Bigliardi, B.; Ferraro, G.; Filippelli, S.; Galati, F. The influence of open innovation on firm performance. Int. J. Eng. Bus. Manag. 2020, 12, 1-14. [CrossRef]

71. Moretti, F.; Biancardi, D. Inbound open innovation and firm performance. J. Innov. Knowl. 2020, 5, 1-19. [CrossRef]

72. Nitzsche, P.; Wirtz, B.; Goettel, V. Innovation success in the context of inbound open innovation. Int. J. Innov. Manag. 2016, 20, 1-38. [CrossRef]

73. Zhang, S.; Yang, D.; Qiu, S.; Bao, X.; Li, J. Open innovation and firm performance: Evidence from the Chinese mechanical manufacturing industry. J. Eng. Technol. Manag. 2018, 48, 76-86. [CrossRef]

74. Hung, K.; Chou, C. The impact of open innovation on firm performance: The moderating effects of internal R\&D and environmental turbulence. Technovation 2013, 33, 368-380.

75. Chiang, Y.; Hung, K. Exploring open search strategies and perceived innovation performance from the perspective of interorganizational knowledge flows. $R$ D Manag. 2010, 40, 292-299. [CrossRef]

76. Laursen, K.; Salter, A. Open for innovation: The role of openness in explaining innovation performance among UK manufacturing firms. Strateg. Manag. J. 2006, 27, 131-150. [CrossRef]

77. Silva, G.; Dacorso, A. Inovação Aberta como uma Vantagem Competitiva para a Micro e Pequena Empresa. Rev. Adm. Inovação 2013, 10, 251-268. [CrossRef]

78. Askarani, D.; Brierley, J.; Yazdifar, H. The effect of innovation characteristics on activity-based costing adoption. Int. J. Manag. Financ. Account. 2012, 4, 291-313. [CrossRef]

79. Kwasnicki, W. Innovation regimes, entry and market structure. J. Evol. Econ. 1996, 6, 375-409. [CrossRef]

80. Yun, J.; Won, D.; Park, K. Entrepreneurial cyclical dynamics of open innovation. J. Evol. Econ. 2018, 28, 1151-1174. [CrossRef]

81. Yun, J.; Liu, Z. Micro- and Macro-Dynamics of Open Innovation with a Quadruple-Helix Model. Sustainability 2019, $11,3301$. [CrossRef]

82. Yun, J.; Zhao, X.; Park, K.; Shi, L. Sustainability Condition of Open Innovation: Dynamic Growth of Alibaba from SME to Large Enterprise. Sustainability 2020, 12, 4379. [CrossRef]

83. Yun, J.; Zhao, X.; Wu, J.; Yi, J.; Park, K.; Jung, W. Business Model, Open Innovation, and Sustainability in Car Sharing IndustryComparing Three Economies. Sustainability 2020, 12, 1833. [CrossRef]

84. Yun, J.; Kim, D.; Yan, M. Open Innovation Engineering-Preliminary Study on New Entrance of Technology to Market. Electronics 2020, 9, 791. [CrossRef]

85. Zhu, X.; Xiao, Z.; Dong, M.; Gu, J. The fit between firms' open innovation and business model for new product development speed: A contingent perspective. Technovation 2019, 86, 75-85. [CrossRef]

86. Spithoven, A.; Clarysse, B.; Knockaert, M. Building absorptive capacity to organise inbound open innovation in traditional industries. Technovation 2010, 30, 130-141. [CrossRef]

87. Alves, R.; da Silva Etges, A.; Neto, G.; Polanczyk, C. Activity-based costing and time-driven activity-based costing for assessing the costs of Cancer prevention, diagnosis, and treatment: A systematic review of the literature. Value Health Reg. Issues 2018, 17, 142-147. [CrossRef] [PubMed]

88. Zhang, Y.; Isa, C. Factors Influencing Activity-Based Costing Success: A Research Framework. Int. J. Trade Econ. Financ. 2010, 1, $1-7$.

89. Neriz, L.; Cruz Fernandez, D.; Rodriguez Araya, D.; Dori Sawada, M. Activity based costs of different units in a high complexity Chilean hospital. Rev. Med. Chile 2020, 148, 17-29. [CrossRef] [PubMed]

90. Tsai, W.-H.; Lan, S.-H.; Huang, C.-T. Activity-based standard costing product-mix decision in the future digital era: Green recycling steel-scrap material for steel industry. Sustainability 2019, 11, 899. [CrossRef]

91. Moradi, S.; Hedayatizadeh-Omran, A.; Janbabaei, G.; Alizadeh-Navaei, R.; Panbehchi, M.; Geraili, B.; Eshaghi, H. Activity Based Costing of Educational Services in Faculty of Medicine in Mazandaran University of Medical Sciences. J. Maz. Univ. Med. Sci. 2018, 28, 86-92.

92. de Sousa Borges, S.; Durelli, V.; Reis, H.; Isotani, S. A systematic mapping on gamification applied to education. In Proceedings of the 29th Annual ACM Symposium on Applied Computing, Gyeongju, Korea, 24-28 March 2014; pp. $216-222$.

93. Vanderlinde, R.; Van Braak, J.; Dexter, S. ICT policy planning in a context of curriculum reform: Disentanglement of ICT policy domains and artifacts. Comput. Educ. 2012, 58, 1339-1350. [CrossRef] 